Article

\title{
CIAM Goes East: The Inception of Tehran's Typical Housing Unit
}

\author{
Hamed Khosravi \\ Architectural Association, School of Architecture, London, WC1B 3ES, UK; E-Mail: hamed.khosravi@aaschool.ac.uk
}

Submitted: 1 April 2019 | Accepted: 24 June 2019 | Published: 30 September 2019

\begin{abstract}
The aftermath of WWII not only marked the beginning of a new geopolitical order but also once again brought discourses of architecture and planning back to the frontline of the confrontations between the West and the Soviet blocs. Although the immediate need for post-war reconstruction left almost no time for contextual theoretical development in architectural and planning principles, the "occupied" and "liberated" territories became laboratories in which the new concepts of urban form, domestic architecture, and forms of life were tested. During 1945-1967 Tehran became one these experimental grounds in which these planning principles were tested and implemented; a battleground where the socialist and the capitalist ideologies met. The key to this urban development project was an ideologically charged repercussion of the CIAM (Congrès Internationaux d'Architecture Moderne) discourse, specifically on Existenzminimum (1929) and Rationelle Bebauungsweisen (1930). While the CIAM's agenda had already found its way to Iran through one of its founding members, Gabriel Guevrekian, it became operative through the activities of the Association of Iranian Architects who were in charge of major housing developments in Tehran since 1945. Thus, CIAM guidelines were translated into building codes, regulations, and protocols that had the fundamental role in shaping the Middle East's first modern metropolis. New housing models were developed and proposed by the Association of Iranian Architects that cut ties with the traditional typologies and proposed a radically new urban form, architecture, and forms of life. This project at large, of course, was not politically neutral. This article reviews the role of two protagonists in introducing and revisiting the CIAM discourse in shaping the post-war neighbourhoods and housing typologies in Tehran.
\end{abstract}

\section{Keywords}

affordable housing; Association of Iranian Architects; CIAM; Existenzminimum; Gabriel Guevrekian; mass housing; Silvio Macetti; Société Générale de Construction en Iran; Tehran; Tudeh Party

Issue

This article is part of the issue "Housing Builds Cities", edited by Luca Ortelli (École Polytechnique Fédérale de Lausanne, Switzerland), Chiara Monterumisi (École Polytechnique Fédérale de Lausanne, Switzerland) and Alessandro Porotto (École Polytechnique Fédérale de Lausanne, Switzerland).

(C) 2019 by the author; licensee Cogitatio (Lisbon, Portugal). This article is licensed under a Creative Commons Attribution 4.0 International License (CC BY).

\section{Introduction}

The early CIAM (Congrès Internationaux d'Architecture Moderne) manifestos, specifically on Existenzminimum (1929) and Rationelle Bebauungsweisen (1930), have been extensively discussed in the context of the European Modern Movement and its agency in the postWWII reconstruction of the war-torn cities in Europe. The extent of the implementation of such ideas, however, was not limited to the European cities of course; they were often instrumentalised as geopolitical apparatuses in post-colonial developments as well as the stateinitiated projects of modernisation. In Iran, the First Pahlavi period (1925-1941) could be seen as one of the most explicit examples of such processes, framed within a wider and more inherent cultural project: the project of modernity. ${ }^{1}$

In Reza Shah's immediate reforms, cities were no exceptions. Tehran's municipal government was among the institutions that the Shah immediately established, how-

${ }^{1}$ In Max Weber's theory, the project of modernity is characterized in terms of "the separation of substantive reason, formerly expressed in religious and metaphysical world-views, into three moments, now capable of being connected only formally with one another (through the form of argumentative justification)". He further elaborates on those three moments as spheres of scientific and knowledge, of morality and of art (Habermas, 1997, p. 45). 
ever, it was not until a decade later that the municipality's administrative structure, its institutional autonomy, and the extent of its spatial practice were fully outlined. Indeed, parallel to that, an idea of city was developed. Between 1927 and 1933, the octagonal boundary and gates were destroyed (Figure 1). All the moats were filled in an effort to reconceptualize the image of the city. Tehran no longer required symbolic representations of religion and power (the reason for the walled city), because it was now completely dependent on its own power of productivity - the mobility of the new capitalwhich was enhanced through the new regulations and infrastructural interventions linking the city centre to its developing industrial periphery. This state-initiated project was also conducted through various construction regulations that were forcefully applied to buildings. The focal point of the new project was housing, aiming to neutralize the old neighbourhoods' socio-political structure by imposing a new urban form, comprised out of openended grid of streets and infrastructure, and new plotted lands, stretched north-south adjacent to the streets. As a result, the architectural typologies of the city were radically changed in a shift that directly impacted the city's social structure. ${ }^{2}$

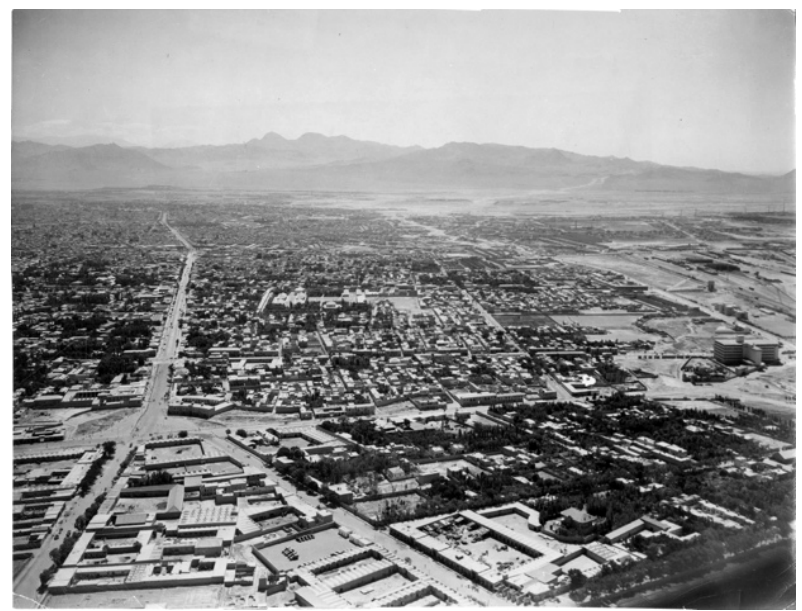

Figure 1. Arial view of Tehran, eastern border of the city, 1942. Source: author's personal archive.

Despite the ever-growing housing needs of Tehran, the post-WWII housing projects seemed to also carry a political agenda. They were designed to instigate the publicin particular, working class and lower middle-class-to fulfil their political duties. The seeds of a revolution were planted in those domestic spaces. One of the main goals of these projects was to reform the traditional role of the housewife. By separating the functions and reducing the flexibility of the space, women were encouraged to go outside the house and work alongside men. Paradoxically, this approach not only criticized the traditional role of Iranian women in an Islamic society but also targeted the new Western role model, which was promoted by the state. The architecture of domestic space was not, in fact, the only instrument for this project; it was widely expressed through the leftist media.

The article revisits the application and modification of the CIAM discourse in shaping the post-war neighbourhoods and housing typologies in Tehran by discussing the role of two protagonists who were fundamental in both initiating the discourse theoretically and ideologically and putting it in practice of urban development in Iran: Gabriel Guevrekian and Silvio Macetti (aka Noureddin Kianouri). Through their initiatives the post-WWII urban development of the city were reduced to simple spatial protocols that have not only shaped the entire urban form of the city up until today, but also have had direct impact on the social form of the city. In fact, very much in line with the CIAM principles, they reformulated the concept of domesticity, living unit, and household, through which the entire city could be built.

\section{Gabriel Guevrekian and the Société Générale de Construction en Iran (1935-1937)}

The inception of the CIAM's discourse on Existenzminimum (Minimum Housing Unit) was rooted in multifaceted economic, political, and social factors; from the post-Revolution Russia's New Economic Policy, to the 1923's Weimar Republic crisis, reorganization of workers' unions and collectivization of labour across Europe, that all were ultimately driven by the 1929's economic recession. In parallel, architectural experimentations such as Hannes Meyer's co-op architecture, or Margarete Schütte-Lihotzky's Frankfurt Kitchen, along with emblematic social housing projects of the time, such as Ernst May's New Frankfurt in 1926 and J. J. P. Oud's Scheepvaartstraat in 1927, boosted architectural discourses on the question of affordable housing, new construction techniques, and minimum living conditions. The subjects of those new spatial organizations were mainly the workers, migrants, and residents of war-torn cities (WWI); specific subjectivities that all can be understood as nomadic and precarious.

Learning from the Middle Eastern forms of habitations, Gabriel Guevrekian, the secretary general of the first CIAM, had already been working with minimum housing since the design of his first project, Hotel Touring-Club, in 1923. His Hotel Touring-Club was a prototypical model that could be expanded in any direction, horizontally or vertically, and that replicated ad infinitum in any region of France. Spaced along the highways at intervals of 300 to 400 kilometers, the hotels were designed to form a network of minimum habitation machines, reduced to the barest formal expression, and distinguishable from each other only by their two-part identifying code, made up of the road number and a letter, for example, A20-A, A4-B, or A8-C (Du Bercel, 1923, pp. 9-10).

\footnotetext{
2 Quite opposite to the traditional courtyard house typology, or urban villas and gardens, the new urban typologies were facing streets, and had direct opening into the public space, their size and orientation were regulated mostly following a module of $7 \times 30 \mathrm{~m}$ stretch of land.
} 
The Hotel Touring-Club was completely selfsufficient, like a small city. In addition to accommodation units, it contained restaurants, a cinema, theater, shops, garages, and car repair workshops. On each level there was a common hall that doubled as a library, with walls decorated with regional maps and bookshelves laden with publications of potential interest to the motorists. Leading off from both sides of the hall were identical series of rooms-smaller ones on the lower floors for the chauffeurs, and suites with bathrooms for their employers on the floors above. Regardless of type, all were fitted out with the minimum of furniture.

A few years later, in the preface to his book on Hôtels et Sanatoria (1931), Guevrekian - the urbane nomadwould locate the origins of the contemporary hotel in the caravanserais and monasteries of the Middle East, pointing out that a certain idea of collective short-stay accommodation had endured, despite the revolution, in the means of transportation. Expanding on the theme, he writes: "Recent social changes have given rise to a new way of living inspired by the idea of staying in a hotel, where a minimum private habitation unit is served by common spaces of work, fun and relaxation" (Guevrekian, 1931, p. 2). This was the kind of collective living embraced by the Hotel Touring-Club de France.

Guevrekian further developed his ideas of minimization of living unit and maximization of collective spaces in his experimental social housing development in Rue du Débarcadère, Paris, in 1929. The project took shape within the framework of Louis Loucheur's new plan to build low-cost housings in Paris. ${ }^{3}$ It was proposed for a deep plot, sided by two typical Parisian apartment blocks. Guevrekian's proposal consisted of four eight-story-high slabs placed one after the other parallel to the street. Between the slabs were 10-meter-wide light wells, through which daylight could be provided to each unit. He provided common facilities on the ground floor where all the units can have access to. However, his innovative design trick was to lift the two middle slabs up on pilotis so that the open spaces of light wells could expand horizontally as a collective platform on the ground level (Figure 2).

Guevrekian designed 186 minimum units in this rather limited plot. The most dominant type was the minimum en-suite studio apartment with an average size of $4.8 \times 7.2 \mathrm{~m}$. The units had been equipped with a kitchenette and a small bathroom. In the last two floors the units were duplex. The living units were all south facing. The northerns slab had studio units with shared facilities; kitchenetts and washrooms were provided in each floor for collective use. On the first slab, facing the street, the larger units were placed on top 6 small shops on the ground floor. Staircases and lifts together with the corridors were linked to the units on the north side. This rather straight-forward organization of the space within an infill Parisian urban block was not anything common back then. It was only two years after that such arrangement of the blocks were discussed the in third CIAM congress where Guevrekian was present as one of the founding members of the organization, handing the organizational responsibilities of the congress to Sigfried Giedion.

At the age of twenty-eight, Gabriel Guevrekian stood in the front row of a group photograph commemorating the founding of CIAM in La Sarraz, Switzerland, in 1928 (Figure 3). Immediately recognizable by his bald head, sharp double-breasted suit, and confident, upright
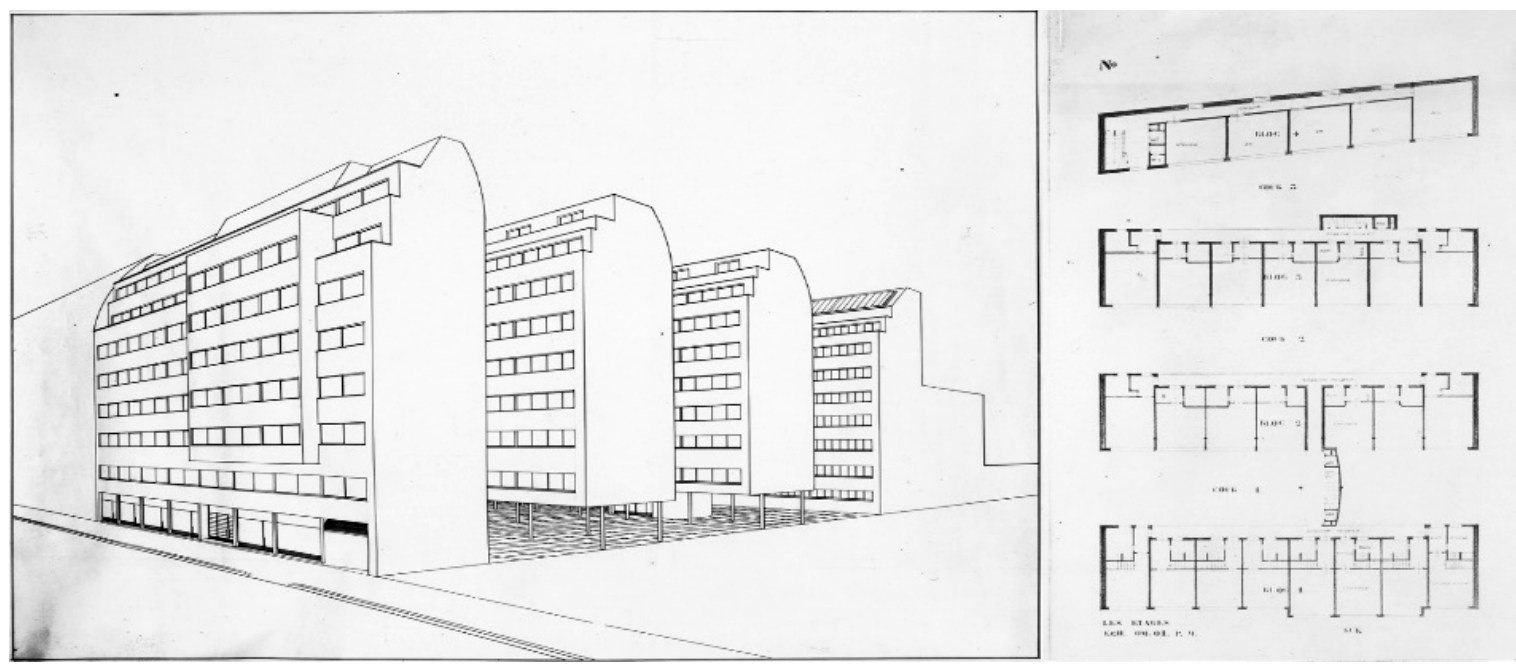

Figure 2. Guevrekian's design for low-cost housing in Paris, 1929. Courtesy of the University of Illinois Library Archive.

\footnotetext{
${ }^{3}$ Louis Loucheur (1872-1931) came from north-eastern France, where he had substantial holdings in the railroads serving the mining regions. Immediately following the war, he served as Minister of the Liberated Zones and led reconstruction efforts in the north. In 1920, he proposed with Bonnevay a law for the construction of 500,000 units of low-cost housing. Although rejected at the time, the proposal later became the basis of the 1928 Loucheur Law, which created the Habitations à Loyer Modéré (rent-controlled housing). For his influence in Le Corbusier's project see McLeod's (1983) Architecture or Revolution: Taylorism, Technocracy, and Social Change.
} 


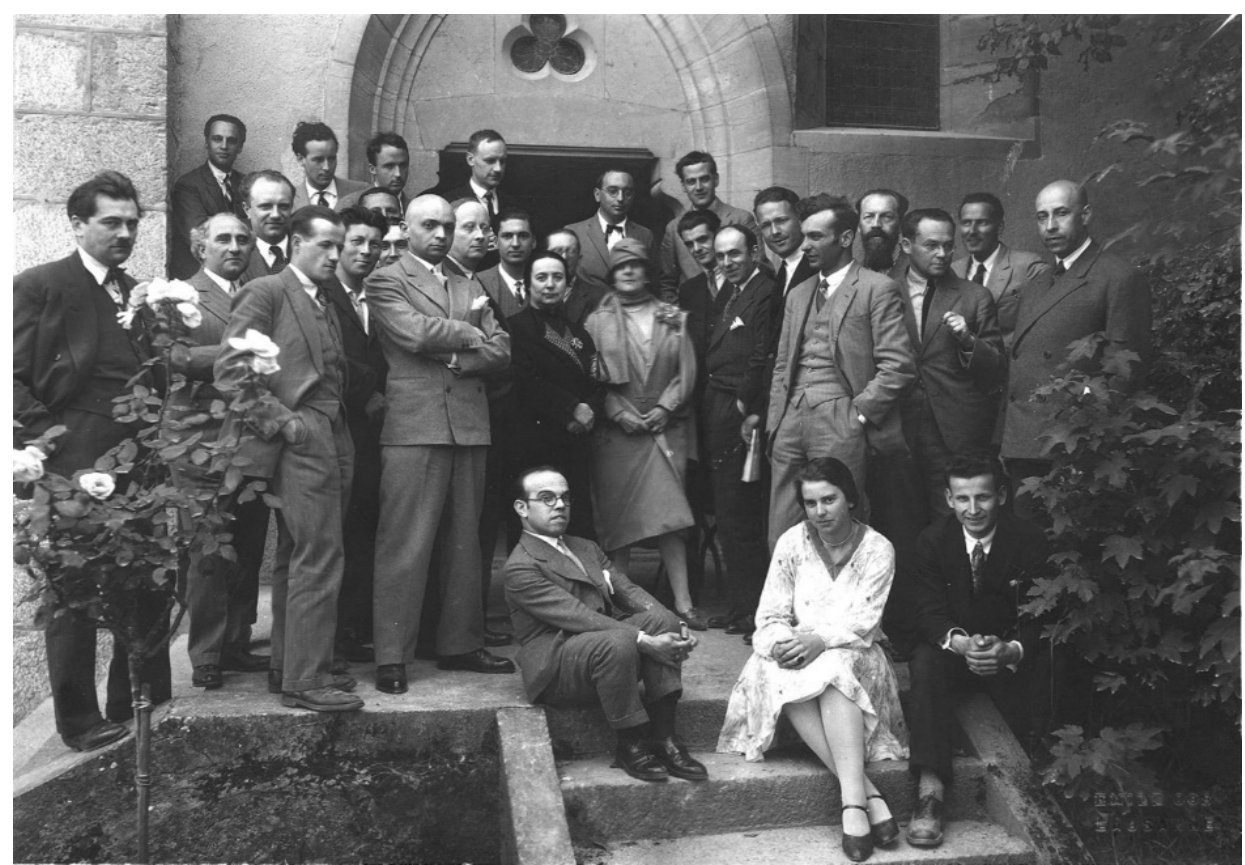

Figure 3. Official group photograph, CIAM I, La Sarraz, 1928. The full list of people in the photo includes, from left to right, top row: M. Stam, M. E. Haefeli, R. Steiger, P. Artaria, F. T. Gubler (press); middle row: R. Dupierreux (Institute Cooperation-Intellectuelle, Paris), P. Chareau, V. Bourgeois, E. May, A. Sartoris (obscured behind Guevrekian), H. Schmidt, H. Häring, J. de Zavala, Le Corbusier, P. Rochat (press), H.R. von der Mühll, H. Hoste, S. Giedion, W.M. Moser, J. Frank; third row: P. Jeanneret (hand in pocket), G. Rietveld, G. Guévrékian, L. Florentin, H. de Mandrot, A. Lurçat (hand in pocket), G. Maggioni; seated: F. G. Mercadal, N. Weber, C. Tadevossian. Source: ETH Zurich, gta CIAM Archive (n.d.).

posture, Guevrekian radiates an obvious assuranceall the more remarkable given that he was standing shoulder to shoulder with many of the leading lights of the modern movement, among them Max Ernst, Mart Stam, Sigfried Giedion, Josef Frank, Gerrit Rietveld, and, skulking toward the back of the group, Le Corbusier. Not yet thirty, Guevrekian was now recognized as one of the protagonists of the European avant-garde. But other roles awaited him. Before another decade was out, Guevrekian had hopped continents to work on a series of monumental buildings and housing projects that were designed to present to the outside world the modern face of Reza Shah's Iran. Then, after a career drought coinciding with WWII, he again moved thousands of miles to take on his final guise, as a genial professor at a Midwestern university.

In an interview with Martin Steinmann, in June 1970, Guevrekian looked back to his early works as the secretary general of CIAM. He recalled how the Swiss art collector and designer, Madame Hélène de Mandrot approached him in 1927 with the idea of organizing a group of avant-garde architects to be able to discuss the crucial issues of the discipline. Guevrekain (1970) voiced:

I knew Madame de Mandrot quite well for many years. She had a nice apartment in the same building at the Rue Champerret in Paris where my brother-in-law the historian Carl Einstein lived. So I met her occasionally. At our first meeting with Le Corbusier at her place-it must be some time in 1927-the overall aims and objectives of the La Sarraz meeting was discussed and Madame de Mandrot with agreement of Le Corbusier insisted that I take care, secure, and carry out the necessary preparations and the secretarial job of the La Sarraz convention. Although at that time I had a very small office and, as a matter of fact, no help whatsoever, I accepted it with pleasure.

He was then named the Secretary General of the congress and charged with the task of assembling the working committee. By April 1928 he had compiled the draft program, which (after some minor revisions by Le Corbusier) would define the structure of the first meeting. In just a few short weeks, modern architecture had reasserted its authority. Being an architectas Guevrekian ably demonstrated-was now no longer simply about designing buildings; it was a matter of cultivating a political persona, proselytizing an ideology, and keeping a shared spirit alive.

In 1932, European economies were in free fall, yet visitors to that year's Vienna Werkbund exhibition would have witnessed the realization of an utopian project-a model housing estate presenting prototypes for much-needed low-cost compact living units. Where the Existenzminimum typologies formulated at the 1929 CIAM Congress reduced costs by means of mechanization and standardization, the Werkbund relied on clever design, in keeping with its core principle of ensuring that 
the less well off, the lower middle and working classes are offered only products that provide joy through their fitness for use and which foster the culture of domestic living (Stuhlpfarrer, 2015).

Thirty-three architects were invited by the Werkbund's director Josef Frank to develop designs for the exhibition. Guevrekian was among a handful of foreign names-along with Gerrit Rietveld, Hugo Häring, and André Lurçat-on a list of participants that otherwise reads like a Who's Who of Austrian modernists, including, among others, Josef Hoffmann, Adolf Loos, Richard Neutra, Oskar Strnad, and Hans Vetter. Guevrekian had no prior experience of building compact living spaces. Up to then his proposals for collective housing and hotel accommodation had remained solely on paper. The commission from Frank, then, was a stimulating challenge, inviting him to develop his ideas for minimum housing units and to apply them in a real-life situation.

First planned as an extension of the housing blocks of Red Vienna, the model estate would eventually be sited in Lainz, a leafy suburb on the outskirts of the city. Josef Frank devised the master plan, dividing the area into seventy plots of 200 square meters, each geometrically outlined in relation to adjacent streets. Strict regulations governing height (a maximum of three stories) and site ratios (the building could occupy up to $40 \%$ of the plot) ensured that the typologically diverse units had a visual coherence.

Assigned two adjacent plots, Guevrekian developed two symmetrical houses-numbers 67 and 68-which were seamlessly joined, as if to form a single unit (Figure 4). Each had a radically simple form, a perfect cube (in some ways developing further the premise of his earlier design for the Ferroconcrete Villa). Each was also raised on pilotis, with a narrow staircase connecting the utility area (laundry, storage, WC) near the entrance with the upper floors. The first floor contained the living room and kitchen, the second floor two bedrooms and a bathroom. The smooth finish of the façades was gently pierced by modulated openings, each one syncing perfectly with the interior composition of the space. Freed from the influence of Mallet-Stevens, Le Corbusier, or Loos, units 67 and 68 expressed an architecture that was entirely Guevrekian's own.

A year after, in 1933, Guevrekian and his wife set off for northeast Asia, stopping first in Tehran to visit family. Immediately, Guevrekian was asked to design two urban villas-one for a family member, the other for some friends, Persian aristocrats. Later that year, Reza Shah appointed Guevrekian as Chief Architect of Tehran. At the time, the city was in the midst of large-scale urban reconstruction as part of the Shah's effort to refashion Iran in a modern image, clearing away all traces of its Qajar past. Guevrekian's first public project was the design of the National Theater. He was then asked to prepare the master plan for Tehran, but when city officials asked for numerous revisions, he refused. Preferring to be his own boss, Guevrekian redefined his relationship with the government, setting himself up as an independent contractor. With a group of French, Swiss, and Iranian architects and engineers, he designed the Ministry of War and an amphitheater for the military school, and he also supervised the construction of the Ministry of Foreign Affairs and the Central Bureau of Records and Archives. Perhaps the most important project to come out of this period, however, was the design and construction of the Officers' Club, a collaborative project with the French engineer, Pénalié, and the Iranian-Armenian architect Vartan Hovanessian, a colleague from his brief time at Henri Sauvage's office (Figure 5). Similar to his

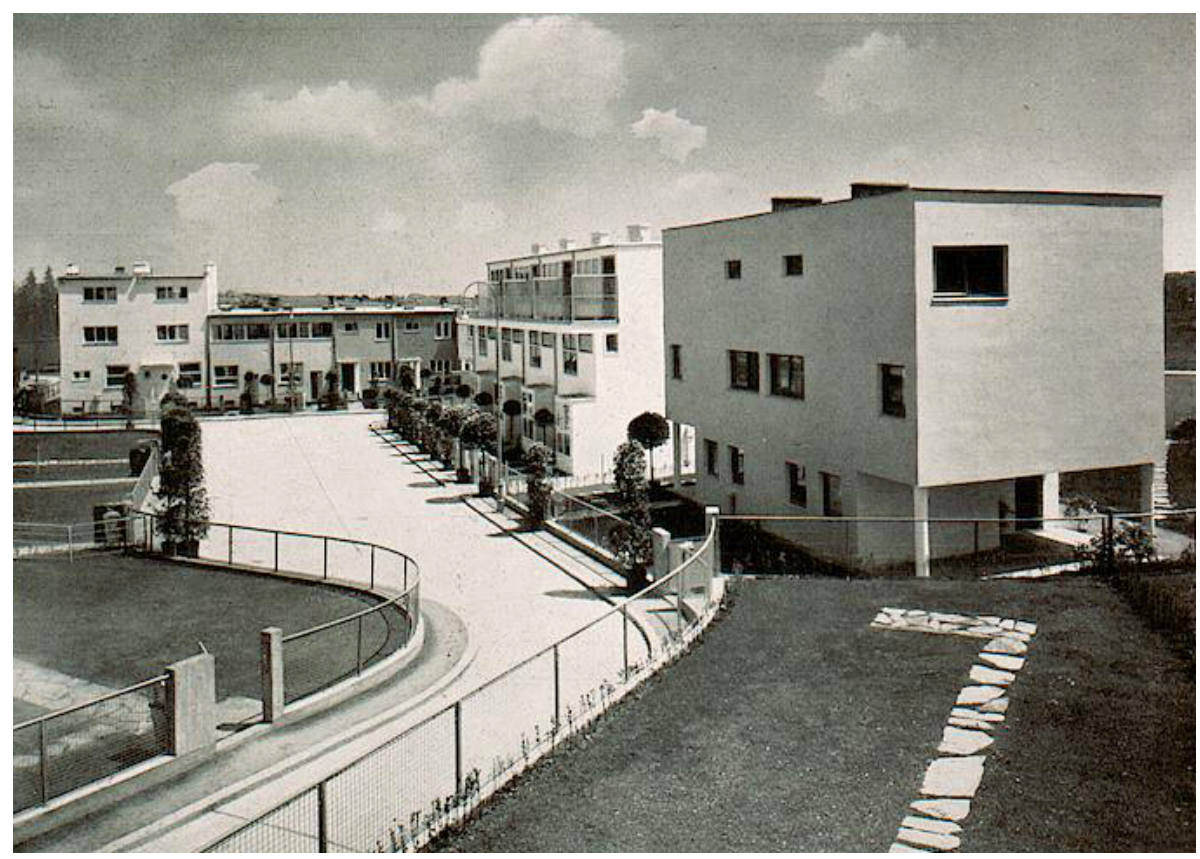

Figure 4. Vienna Werkbundsiedlung, houses numbers 67 and 68, 1932. Source: Innen-Dekoration (1932). 


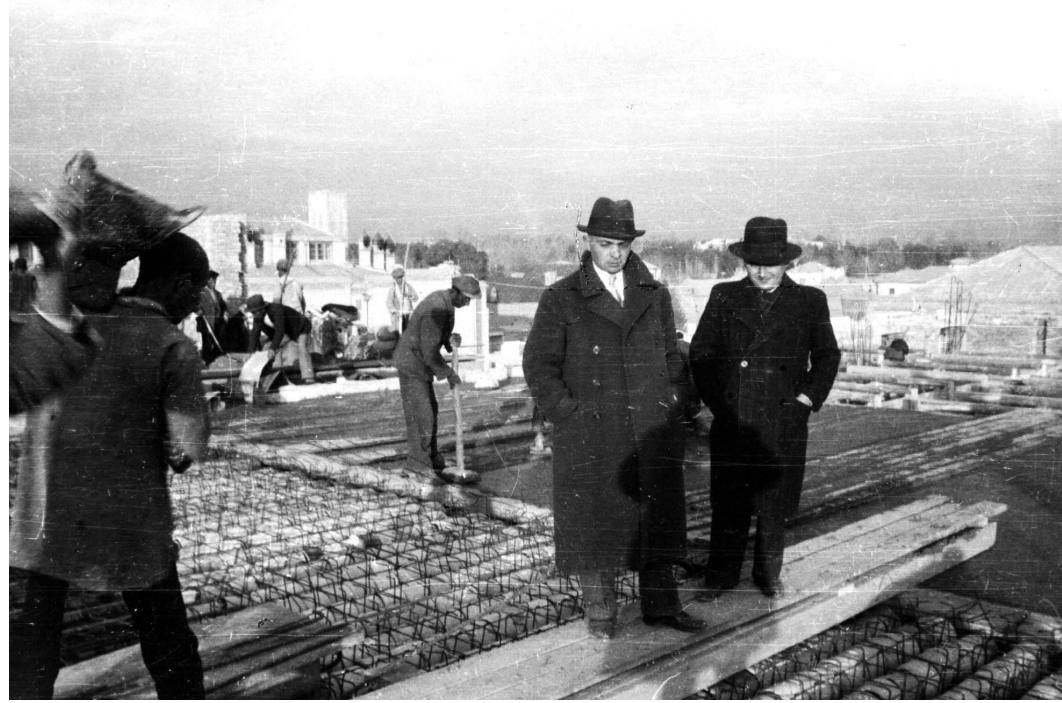

Figure 5. Gabriel Guevrekian on the roof of the Officers' Club, 1937. Source: Le Groupe d'Architectes de l'Ere de Evolution en Iran (n.d.).

European projects, Guevrekian designed every last detail of the crisp five-story building, right down to the bricks, which were custom-made to achieve the correct proportions of walls and openings. Lavishly appointed, the club was decked out with the most advanced building services: the elevators, central heating system, and sanitary fittings were all imported. To balance construction costs, Guevrekian combined these imports with local skills and materials, developing many innovative construction techniques in the process.

Two years into his Persian sojourn, Guevrekian was invited by the Minister of Finance, Ali-Akbar Davar, to run the technical department of the Société Générale de Construction en Iran, which coordinated all public building activities in the city. In this capacity, Guevrekian designed the masterplan of Tehran governmental quarter together with the French architect Marcel Dubrulle. They also proposed schemes for the Palace of Justice and the Ministry of Industry and Mines. The activities of the Société Générale de Construction were all suddenly stopped with the suspicious death of the Minister in the February 1937. Right after the dismissal of the office Guevrekian faced another unexpected problem; his wife, Henriette-Aimee, had been diagnosed with Malaria. They left Tehran immediately in March 1937. Although Guevrekian's career in Tehran lasted only four years he enjoyed the most productive period of his professional career. He later expressed his deepest regrets to live the country where he had initiated an architectural movement and had left behind fascinating body of works, most of which are not known outside Iran. As Guevrekian himself pointed out, his Iranian projects cannot be compared directly with the European ones; firstly because of the particular geographical and environmental condition of country and secondly due to limited building materials and traditional construction techniques. Indeed, it was impossible to copy or to transpose any
European architecture to Tehran, but what Guevrekian achieved through his projects was to establish an Iranian Modernism Architecture. Rather than a top-down imposition of the Royal will, Guevrekian saw the social changes in Iran as the most influential driving force behind the general support and acceptance of the modern architecture of the city (Guevrekian, 1938).

These social changes accelerated in the years after. Although outshined by the war and the occupation of Iran by the allied forces, but the aftermath of the WWII once again brought discourses of modern architecture and planning back to the social, political, and economic agendas of the country. Although the immediate need for post-war reconstruction left almost no time for a contextual and theoretical development in architectural and planning principles, the big cities, and in particular Tehran, became laboratories in which the new concepts of urban form, domestic architecture, and forms of life were tested. Such experimentations consequently put Tehran on the frontline of the confrontations between the West and the Soviet blocs; an ideological battleground where the joint socialist modernism and the capitalist one met.

\section{Silvio Macetti and the Association of Iranian Architects (1945-1967)}

In August 1941, the Anglo-Soviet invasion of Iran had inaugurated an interregnum that lasted a full twelve years. It was the beginning of a period in which the new monarch, Mohammad Reza Shah, continued to hang on to much of the armed forces but lost control over the bureaucracy and the system of patronage. This interregnum lasted until August 1953 when the Shah, through a coup engineered by the Americans and the British, re-established royal authority, thereby recreating his father's regime and enabling him to act as an executive 
monarch for the next twenty-five years. In this twelveyear interregnum, power was not concentrated in one place. On the contrary, it was hotly contested between the royal palace, the cabinet, the parliament, and most importantly the urban masses, whom were mobilized first by socialist movements and then by a nationalist one. Indeed, in this period the masses, mainly made up of the urban middle class and working class, constituted a major threat to the Pahlavi Dynasty.

The first real challenge to the state came from labour movements. On 29 September 1941, within a month of Reza Shah's abdication, a group of recent graduates from European universities and former political activists announced the formation of an Iranian communist party: the Tudeh Party (the Party of the Masses). Besides their political activities in the form of demonstrations and gatherings, they set out to train and educate the public, specifically the working and middle classes. During 1946 the Tudeh Party extended its activities with a view to mobilizing middle-class, working-class, and intellectuals. The mission resulted in the formation of numerous groups, circles, and clubs as sympathizers of the Tudeh Party or associated organizations, namely Women's Association, Youth Association, Officers' Organization, Students' Association, Writers' Association, and Association of Iranian Architects.

The role of Association of Iranian Architects was quite fundamental; the discourse of domesticity was at the centre of their political programme to mobilize urban society, addressing women (workers) in particular as a forgotten half of the active political mass. Their ideology was influential in the design and construction of mass housing projects in Tehran during the late 1940s and 1950s. The association launched its own journal,
Architect, in order to reach a larger audience. It soon became quite popular and were distributed countrywide. The association was composed of figures who collaborated with Guevrekian or were introduced to his discourse as young students in Europe. The founding members were Vartan Hovanessian (Guevrekian's collaborator and graduate from École Spéciale d'Architecture of Paris in 1923), Mohsen Foroughi (graduate from École des Beaux Arts in Paris in 1934), Ali Sadeghe (garduate from Académie Royale des Beaux Arts in Brussels in 1936), Keyghobad Zafar (graduate from Royal College of Art in London in 1936), Manouchehr Khorsand and Abbas Ajdari (both were graduates from École des Beaux Arts in Paris in 1937), and Noureddin Kianouri (graduate from Technical University of Aachen in 1939).

Among the founding members, Kianouri was a key figure that theoretically and ideologically laid out the mission of the association. He was a graduate of Tehran University. He later moved to Germany and obtained his doctorate in architecture from the Technical University of Aachen in 1939. A year later he returned to Iran and in 1945, together with the other founding members, he co-founded the Association of Iranian Architects. Despite his academic career at the University of Tehran and his professional work as an architect, he was a leftwing activist. Kianouri was one of the founding members of the Tudeh Party in 1941. However, on 4 February 1949, Tudeh was accused of the assassination attempt on the Shah during an annual ceremony to commemorate the founding of the University of Tehran. The party was subsequently banned and most of the party leaders were imprisoned (Figure 6). After two years in jail Kianouri escaped from prison and fled first to Iraq and then to Italy. There, with the help of the Italian Commu-

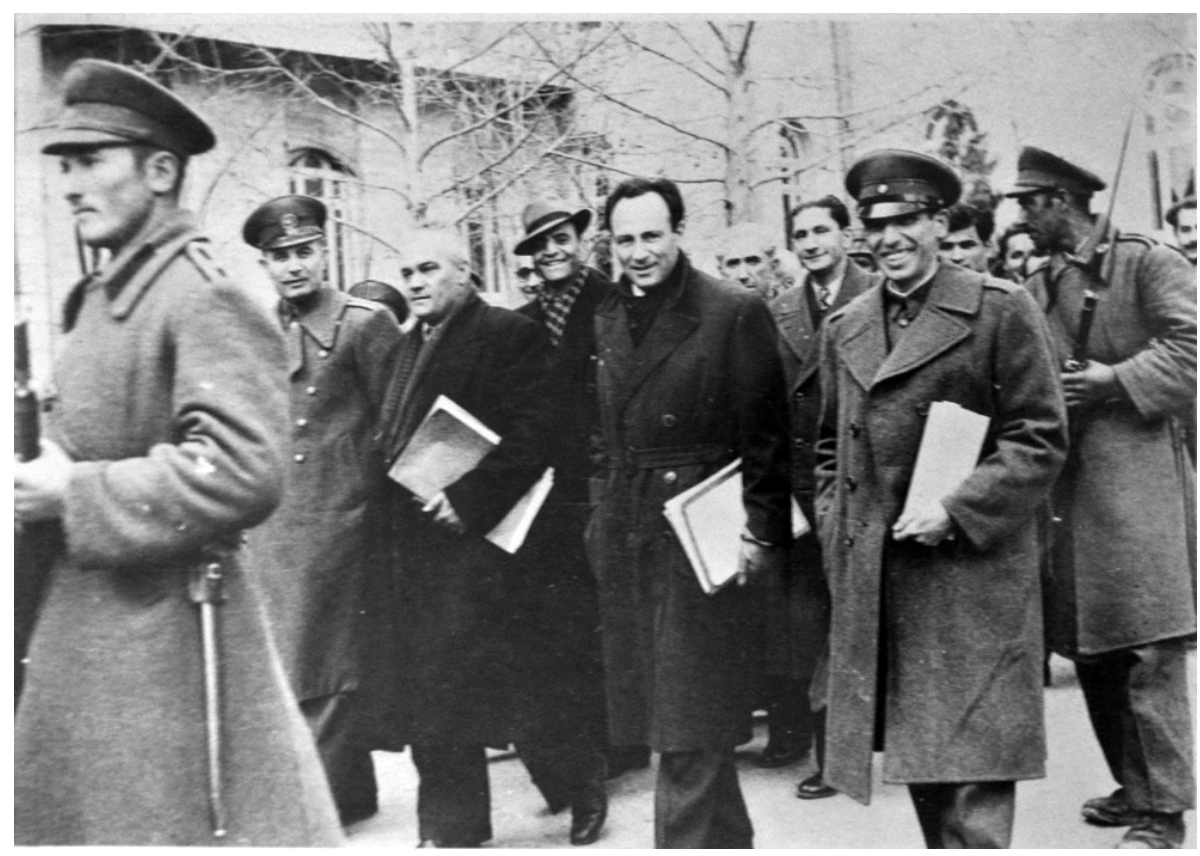

Figure 6. Noureddin Kianouri (centre) and Morteza Yazdi (left) from Tudeh Party are being taken to the court, 1949. Source: Afsaneh Gidfar family archive. 
nist Party he was given a new identity as Dr Silvio Macetti. In 1952, he moved to Moscow, there Silvio (aka Kianouri) worked with the architect and urban planner Georgy Alexandrovich Gradov for two years, during which time the first phase of a larger institutional research project began. In 1956 Macetti moved to East Germany and was later appointed as one of the research directors of the Bauakademie to collaborate with the research institute at the Academy of Architecture in Moscow, directed by Gradov.

The two research institutes, the Academy of Architecture in Moscow and the Deutsche Bauakademie in Berlin (DDR), were put in charge of running this extensive research project. The project was to establish and promote the theory of what was to be called "socialist architecture", aligned with the new social structure and technological advancements of the time and a vision for the future. The two architects were tasked with revising the fundamental ideology of socialism and applying it in a Neufert-like handbook of socialist architecture, proposing new typologies of collective habitation, public institutions, and urban form, and developing new planning principles for the territories.

The twenty-year research collaboration resulted in the publication of two books: Großwohneinheiten (1968) by S. Macetti and Stadt und Lebensweise (1971) by G.A. Gradov. Both authors published many journal articles and research reports, a number of which appeared in Deutsche Architektur. However, the joint research project was never finalized: many manuscripts and proposals remained on paper and were never published. Thus, it is difficult to evaluate to what extent such a theoretical project was actually implemented and promoted by the two institutions in planning new settlements and developing architectural typologies for minimum unit and mass housing. However, the migration of the ideas and application of these principles of co-habitation and a new socialist way of living could be traced along with the multi-faceted life of the leading figure.

For Macetti the key to make any social and political change in the society lied in the question of domestic space; a space that no more about fulfilment of the necessities, desires, and needs of the individuals, but rather is about the collective mobilization of those lives through maximization of the communal facilities and minimization of the living units to the bare essential infrastructures. The city and the society indeed were the ultimate targets of the project; where political dimension of life can be exercised. He directly refers to the CIAM principles in his book, and suggests that although they are currently serving the capitalist societies however they could be read differently and instrumentalised for the mobilisation of the society:

Responding to housing demands remains the original task of building science and architecture. According to the theses of the CIAM, outlined also in the 'Athens Charter' in 1933, housing is associated with one of the four major functions of the city: work, housing, recreation, and transport. However the concept of living and housing in the 20th century, as a result of the development of social life, has gone beyond the mere function of the dwelling to which it was formerly limited. Today living no longer encompasses only the private part of human life, but is an essential and dynamic part of the entire system of life. Living no longer takes place in isolated homes, but rather in an active encounter with the associated communities and their facilities (city)....The habitation factors and the material-technical and cultural backwardness of the capitalist past are overcome fundamentally.... House should be a space for a meaningful life, for the economy of the time, for reaching a higher cultural level, for better working and living conditions, for emancipation of the woman, for better conditions for the care and education of the children; These are considered by many outstanding architects of the capitalist world as well, and are taken up in their works to fulfil them progressively. This is how the work of Le Corbusier should be understood and judged. (Macetti, 1968, pp. 11-13)

Although Macetti (aka Kianouri) was not personally involved in designing and planning the mass housing projects in Iran, he served the architectural movement through his theoretical and ideological input. Indeed, it could be claimed that he established, if not developed, the CIAM discourse of minimum unit and mass housing in Iran parallel to the progression of the research project. The other members of the Association of the Iranian Architects, such as Manouchehr Khorsand, Ali Sadeghe, Mohammad Elahi, Mohammad-Ali Sheybani, Abbas Ajdari, Iraj Moshiri, Siavash Kasraei, and Nasser Badi'e, most of whom were official or affiliated members of the Tudeh Party, took the lead.

The Association soon became the only organization the systematically criticized, envisioned, and discussed the problems and the possible futures of architectural discourse and discipline in the country. For them the urgent problem to be addressed was housing. In the first issue of the Architect journal (from August 1946), Abbas Ajdari outlined the mission of the association in the article "The Problem of Housing in Tehran, and other Cities". There he pointed out that the post-war migration and industrialization have caused overpopulated areas in the outskirt of the city with no proper infrastructure and living facilities. Planning affordable mass housing for the working class and the lower middle-class was the answer. Ajdari's proposed solution was new forms of urban development according to the modernist principles of planning (Ajdari, 1946). These models were discussed more in detail in another article in the same issue of the journal, "First Ideas for Collective and Affordable Housing in Iran". Mohammad-Ali Sheybani, the author, describes his meeting with Louis Loucheur, former French minister of Labour, Hygiene, Welfare Work, and Social Security 
Provisions, who had famously helped Le Corbusier solving some legal problems surrounding Pessac and had supported his investigations on low-cost mass housing typologies and construction techniques: Dom-ino, Monol, Citrohan, and the Immeuble-Villas. Sheybani writes that he had compiled a preliminary proposal for planning affordable mass-housing in Tehran-based on Loucheur's ideas and the French experiments-and discussed it with Ali-Akbar Davar, Minister of Finance (Sheybani, 1946). The plan had the full support of the Minister and was commissioned to the Société Générale de Construction, under Guevrekian's supervision, for further development and implementation. However all the plans were halted following the death of the Minister and Guevrekian's return to Europe. The author sees the Association of Iranian Architects as the successor of the former attempts in order to systematically develop low-cost mass housing project for the country (Sheybani, 1946).

Following the enactment in 1944 of the Law of Affordable Housing for Working Class and Governmental Employees initiated in the parliament by the Tudeh Party fraction, the Association of Iranian Architects developed a series of social housing projects in Tehran: the Chaharsad Dastgah (1944-1946), the Kuy-e Narmak (1951-1955), the Kuy-e Nazi Abad (1951-1958), the Kuy-e Nohom-e Aban (1961-1963), and the Kuy-e Kan (1961-1964). The new neighbourhoods were all planned according to the modernist principles of hygienic facili- ties, sufficient daylight, clean water supply, and vehicular accessibility. The new typologies were collective housing with minimum units. The total areas of these new neighbourhoods combined were more than the size of the city itself (Figures 7 and 8).

Not surprisingly, these projects were planned next to the industrial areas and factories around the city in order to accommodate the working class. Following the ideas propounded by Macetti's visionary socialist architecture, most of these housing projects were equipped with communal spaces at both the block and neighbourhood scales, where meetings, social exchange, and political gatherings and demonstrations could take place.

The initial idea of these projects was to build highdensity quarters with tall slabs, quite similar to the typologies that Macetti had proposed. However, owing to a lack of financial support and sufficient executive power to be able to afford and introduce such technologies for large-scale blocks, the Association of Iranian Architects decided to develop the projects with low-tech construction and low-cost building materials and techniques. The plan of the dwelling units was reduced to a bare minimum of spaces, series of bedrooms with almost no living room or spacious kitchen, as used to be the case in traditional Iranian houses (Figure 9). The projects were provided with day-care centres, public laundry facilities, and, of course, community spaces most of which were later converted to Tudeh Party clubs. For them the social, political, and economic performance of the projects

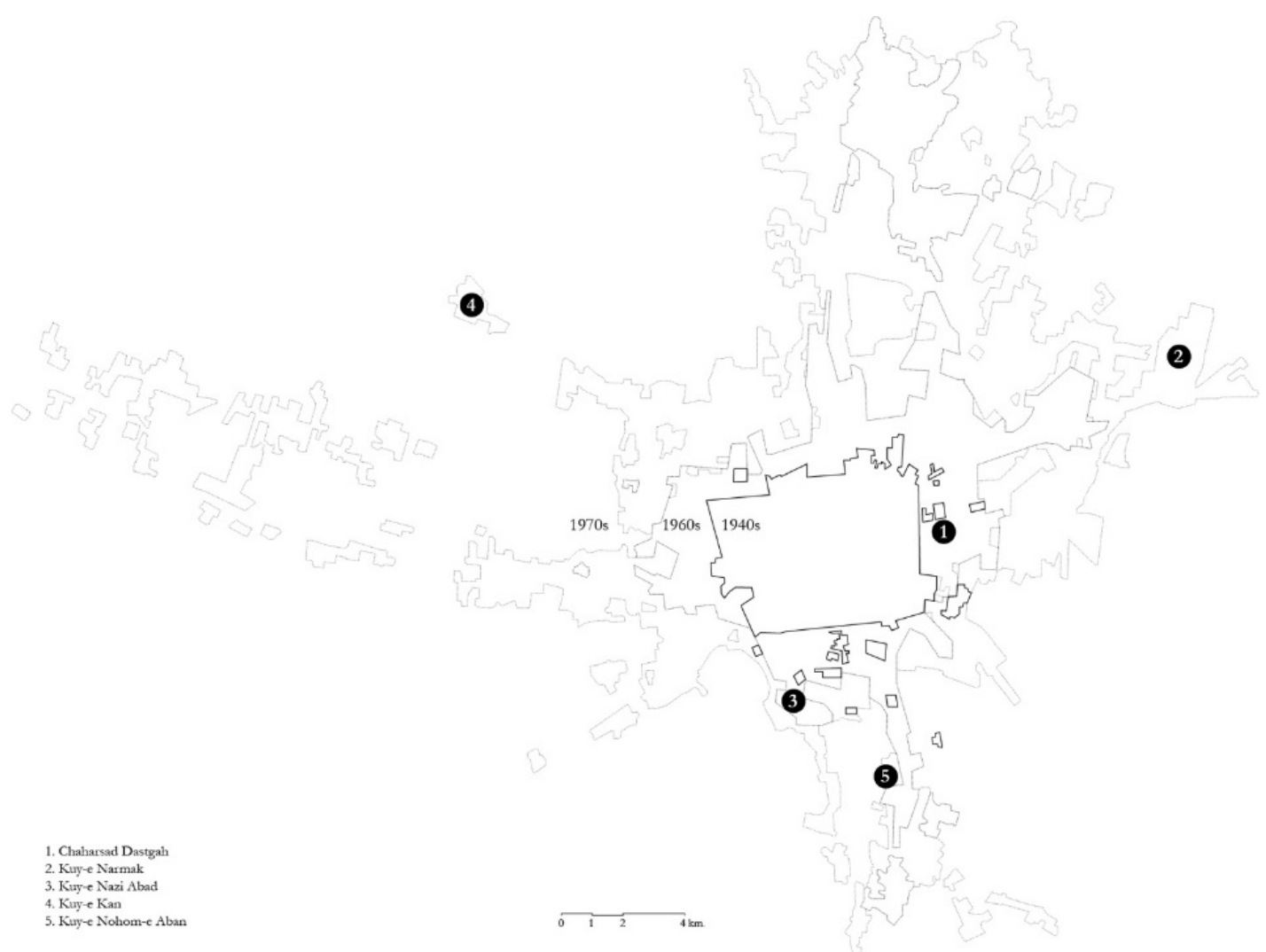

Figure 7. Tehran's Urban Growth (1940s to the 1970s) and the locations of the early social housing projects. Source: author. 


\section{COGITATIO}

田
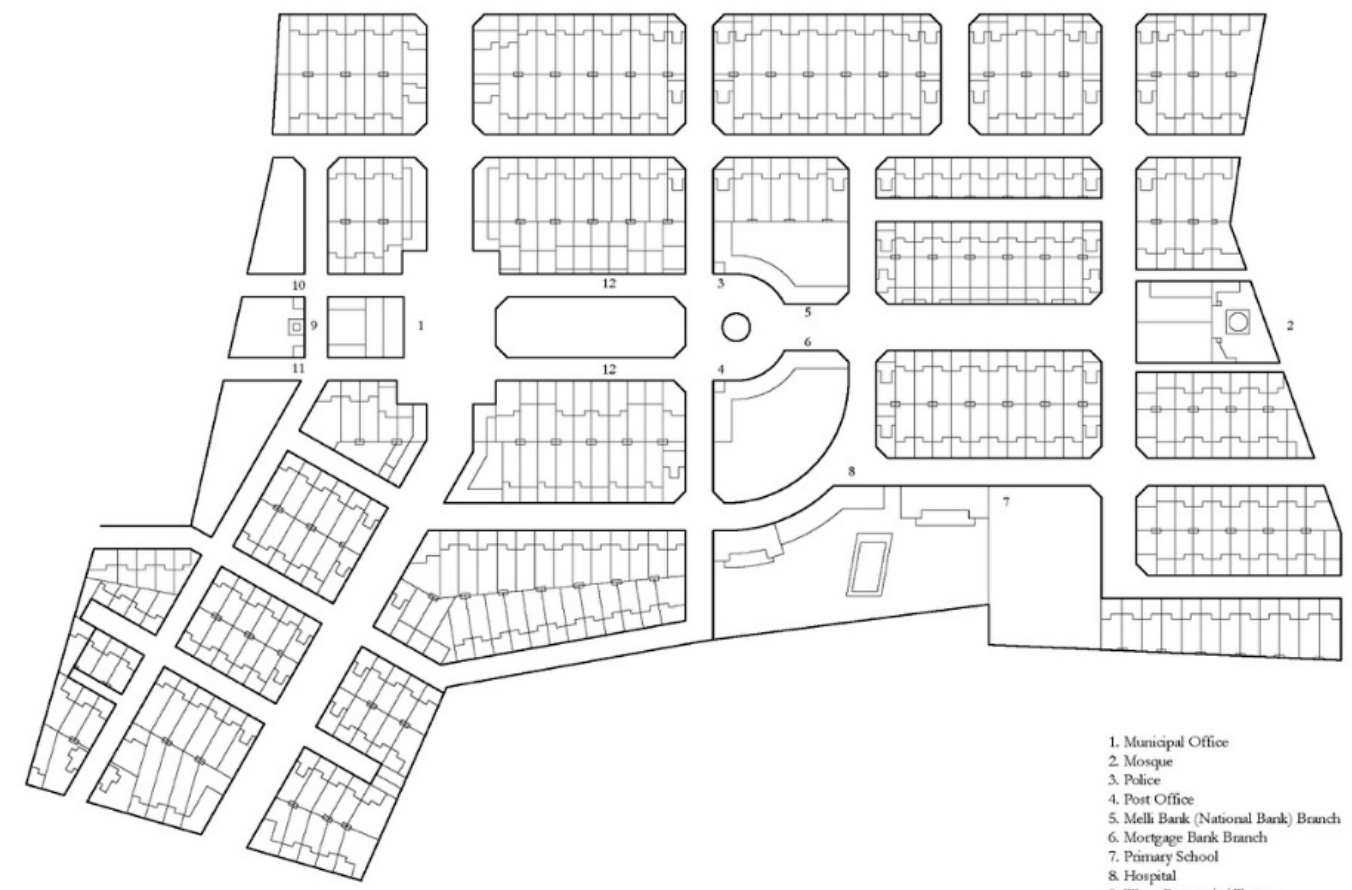

1. Muniapal
3. Mosque
3. Police

4. Post Office

5. Melli Bank (National Barkik) Branch

6. Mortgage Bank Branch

7. Pimary School
8 Hospital

9. Whapter Reservoir/Tower

10. Waundry

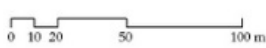

11. Bath Houre

12. Shops

Figure 8. Plan of Chaharsad Dastgah housing project. Source: author.

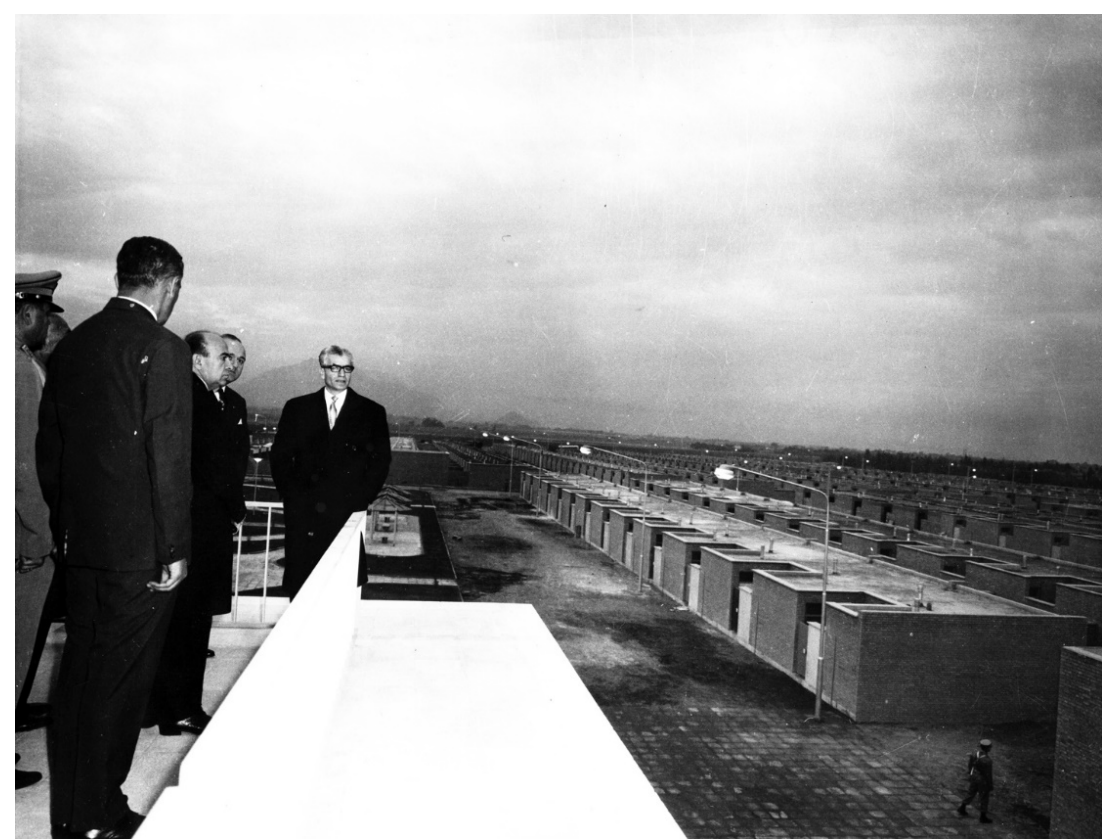

Figure 9. Kuy-e Nohom-e Aban, mass housing project in Tehran, 1962. Source: IICHS (n.d.).

was the absolute priority. The design of the housing typologies thus strictly followed the ideas for the socialization of the household tasks promoted by Silvio Macetti (Kianouri):

Today we live in a great era; it is the era of revolutionary transformation for the whole society, the age of a worldwide transition from capitalism to socialism. This transformation of the world opens up new perspectives on the spiritual and material conditions of human life....Like every realm of human activity, architecture is also under the decisive influence of these overall processes. As architects and urban planners [our] first and foremost duty is to adapt the built en- 
vironment of the society to the demands of the socialist way of life....To constantly provide housing for more people and to offer them such a cultural and living milieu as affects the development of individuals as well as society. This [new] form of living must comply with the requirements of our time and the socioeconomic performance of the space in order to foster a high degree of socialization in household tasks. (Macetti, 1968, p. 8)

\section{Conclusions}

In these projects, which were mainly made for the working and the lower income classes, architecture was re- duced to its barest form, and facilities were at the minimum. In this way, the dwellers' lives were administered, controlled, and shaped through series of spatial protocols and concrete measures. These ideological projects were later turned into codes and regulations, proposed by the 1963-1967 masterplan of the city; simple protocols of minimum housing units through which an entire city was formed. Within three decades the typologies experimented in those mass housing projects occupied the entire extent of the territory; an expanding lava of urbanisation spread between the mountains in the north and the desert to the south (Figures 10 and 11).

Tehran's typical apartment was in fact born out of such ideological recuperation of the modernist princi-

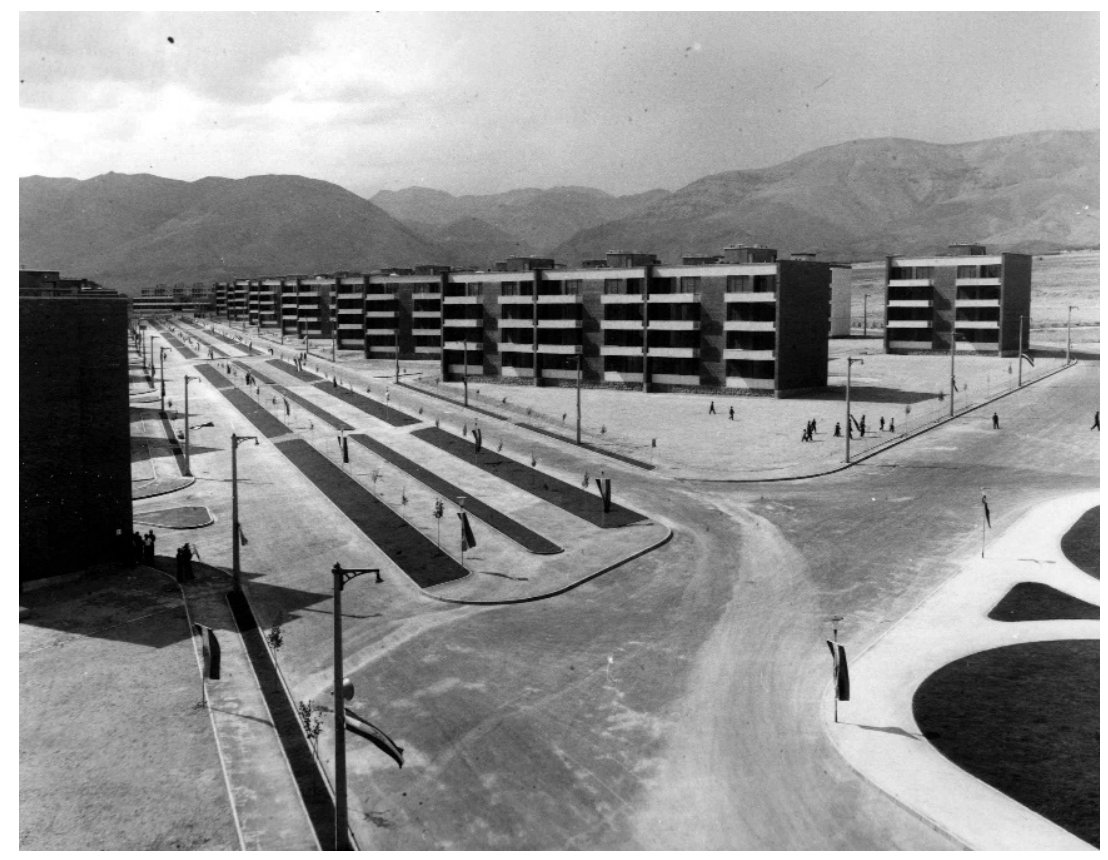

Figure 10. Kuy-e Kan, mass housing project in Tehran, 1964. Source: Iran National Library Archive (n.d.).

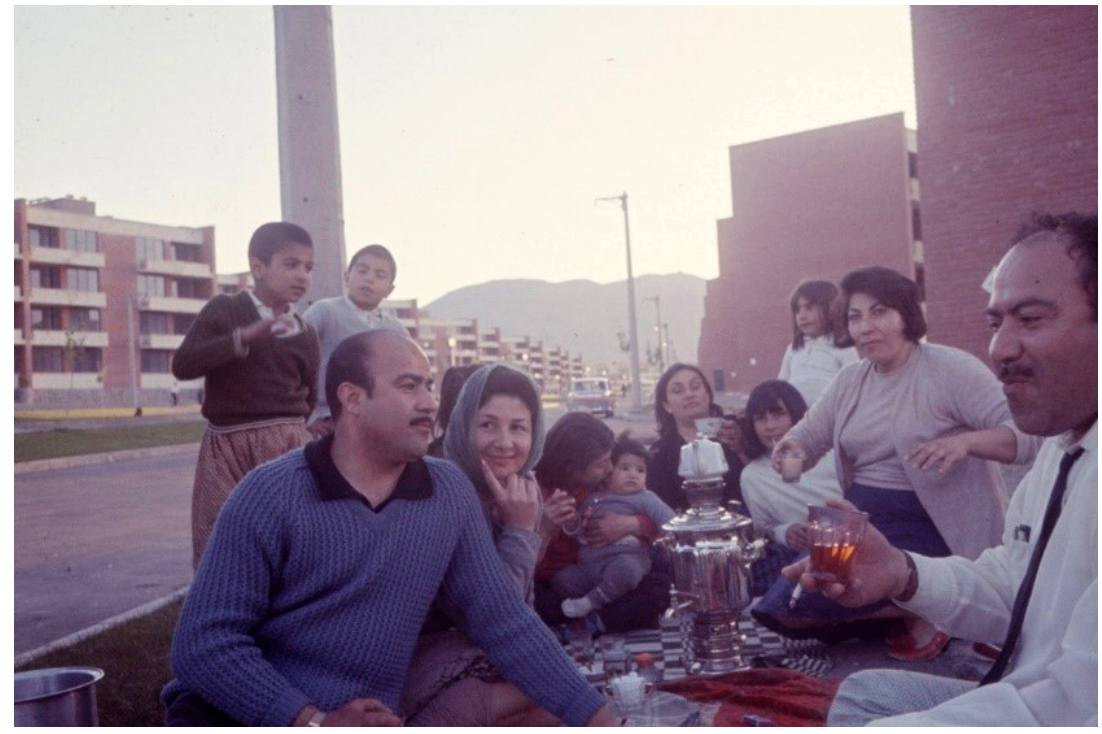

Figure 11. Kuy-e Kan's residents using the side-walks as a collective space for gathering and eating, 1964. Source: LIFE (n.d.). 


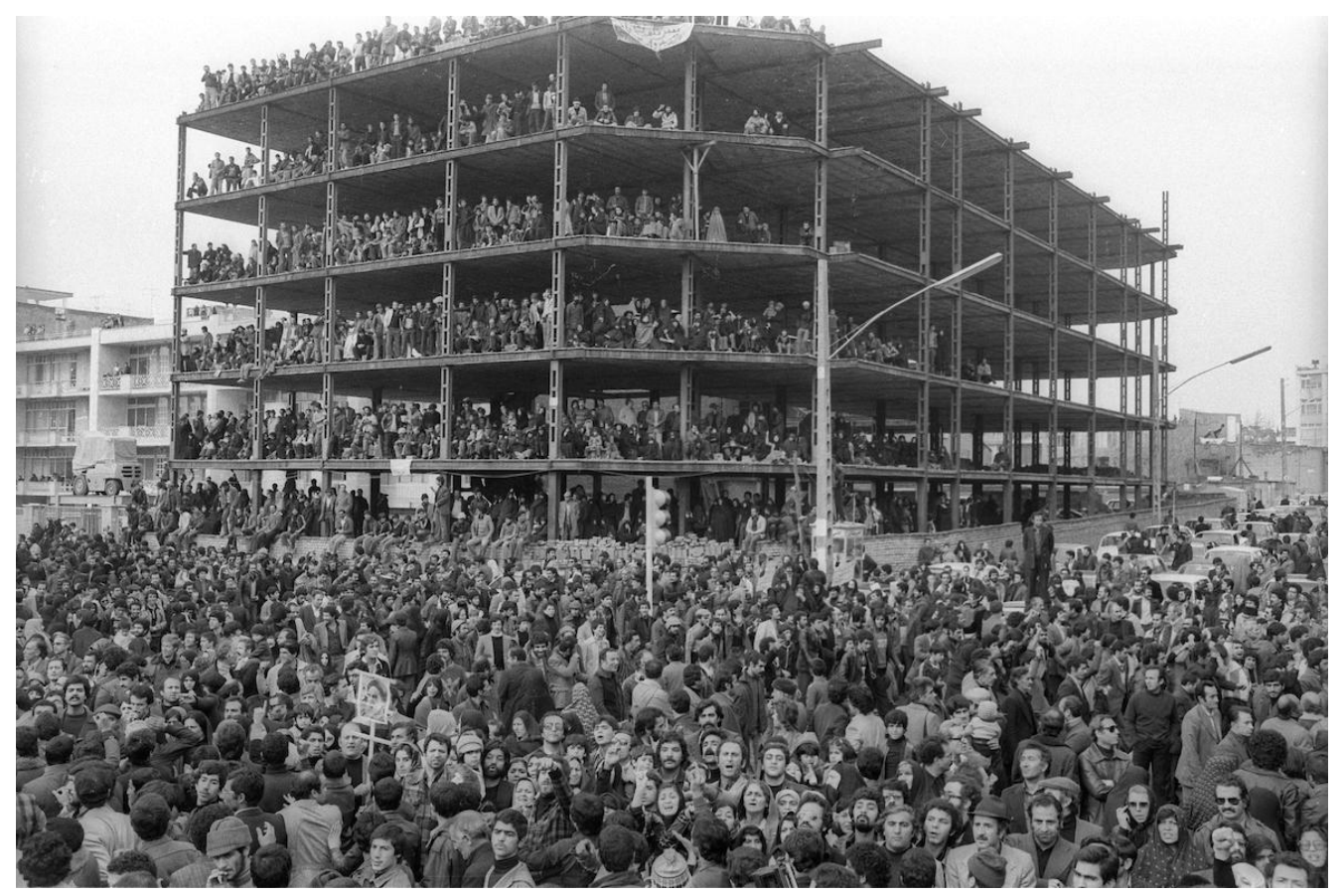

Figure 12. Islamic Revolution, February 1979. Source: Michel Setboun.

ples of urban development. Bare frames that expanded Corbu's dom-ino into a five-story apartment, raised on Guevrekian's common pilotis, equipped with SchütteLihotzky's Frankfurt kitchens, and laid out following to Gropius's Zeilenbau's grid; an infrastructure that could accommodate any form of life. Such characteristicsnamely domestic space as an infrastructural frameblurred the strict division between public and private space, between the space of living and space of political action. Consequently, the practice of citizenship is not anymore limited to the city but also flourished within the interiors of the domestic spaces. When public space is policed and controlled, domestic interiors become not only art galleries, clubs, spaces for rituals, cultural centres, workshops, and offices, but spaces for political action. Interiors cease to be the exclusive domain for individual life and family matters; houses become the spaces in which new forms of collective life are experimented and nurtured, and the battleground for social conflicts and political constituencies. Such a specific collective dimension proper to Tehran-more than private, but not yet public. At the same time some of the domestic activities extend their domains to the public realm, where the life itself becomes a political project (Figure 12).

As Macetti aimed for, these generic frames have enabled a dialectical relationship, deliberately mobilizing the city and the society through the conditions of isolation and association, paving the way for a continuous revolution that in fact begins at home.

\section{Acknowledgments}

The author would like to thank Marina and Simon Guevrekian (Gabriel Guevrekian's family) and Afsaneh
Gidfar (Silvio Macetti's family) for their support and generosity in sharing memories and family archive with the author.

\section{Conflict of Interests}

The author declares no conflict of interests.

\section{References}

Ajdari, A. (1946). Mas'ale-ye tahiye maskan dar Tehran va shahrestan-ha [The problem of housing in Tehran and other cities]. Architect, 1(1), 15-16.

Du Bercel, J. (1923). Les hôtels-relais de M. Guevrekian; une nécessité du tourisme moderne [Motel by Mr. Guevrekian; a necessity of modern tourism]. Art et Industrie, 1(2), 9-10.

ETH Zurich, gta CIAM Archive (n.d.). GTA archives. ETH Zurich. Retrieved from https://archiv.gta.arch.ethz. ch

Guevrekian, G. (1931). Hôtels et Sanatoria [Hotels and sanatoria]. Paris: Éditions S. de Bonadona.

Guevrekian, G. (1938). Habitation A Téhéran [Housing in Tehran]. L'Architecture d'Aujourd'hui, 6(1), 78.

Guevrekian, G. (1970). Interview with Martin Steinmann. Zurich: ETH Zurich, gta CIAM Archiv.

Habermas, J. (1997). Modernity: An unfinished project. In M. P. d'Entrèves \& S. Benhabib (Eds.), Habermas and the unfinished project of modernity: Critical essays on the philosophical discourse of modernity (pp. 38-55). Cambridge, MA: MIT Press.

IICHS. (n.d.) Institute for Iranian contemporary historical studies. IICHS. Retrieved from http://iichs.org/index_ en.asp 
Innen-Dekoration. (1932). Interior decoration: My home, my pride; the whole apartment art in picture and word. Heidelberg Historic Literature-Digitized. Retrieved from https://digi.ub.uni-heidelberg.de/ diglit/innendekoration1932/0292/image

https://digi.ub.uni-heidelberg.de/diglit/ innendekoration1932/0292

Iran National Library Archive. (n.d.). National library and archives of the Islamic Republic of Iran. World Digital Library. Retrieved from http://www.nlai.ir/home

Le Groupe d'Architectes de l'Ere de Evolution en Iran (n.d.). Architecture of changing time. Architectureoct. Retrieved from http://architecture-oct.com

LIFE. (n.d.). LIFE photo archive. LIFE. Retrieved from https://artsandculture.google.com/partner/lifephoto-collection
Macetti, S. (1968). Großwohneinheiten [Large-scale housing]. Berlin: VEB Verlag Für Bauwesen.

Michel Setbound. (n.d.). Iran Islamic revolution. Setbound Photo. Retrieved from https://www.setbounphoto.com/

McLeod, M. (1983). Architecture or revolution: Taylorism, technocracy, and social change. Art Journal, 43(2), 132-147.

Sheybani, M. A. (1946). Peydayesh-e fekr-e tahiyehe sakhteman-e khaneh-haye dast-e-Jami'i-e arzanbaha dar Iran [First ideas for collective and affordable housing in Iran]. Architect, 1(1), 28.

Stuhlpfarrer, A. (2015). The Austrian Werkbund. Werkbundsiedlung Wien. Retrieved from http://www. werkbundsiedlung-wien.at

\section{About the Author}

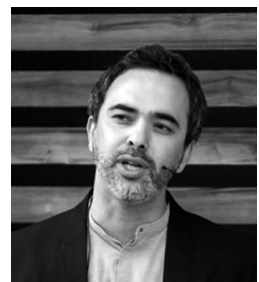

Hamed Khosravi is an architect, writer, and educator. He has taught at the Architectural Association, Berlage Institute, Oxford Brookes University, and TU Delft Faculty of Architecture. His research and projects focus on the history and theory of architecture and urban form, in relation to territorial organisations and political decisions. Khosravi's writings include Wake Up! An Anthology of Bidari-e Ma (2019), The Nomos of the Sea (2018), Inhabitable Walls (2016), Geopolitics of Tabula Rasa (2014), among others. He is the editor of the books Aesthetics and Politics of Logistics (Humboldt Books, 2019) and Tehran: Life Within Walls (Hatje Cantz, 2017). 